\title{
A Child-friendly Family Education in the Perspective of Psychology
}

\section{Eti Nurhayati}

Received: 24102016 / Accepted: 1312 2016 / Published online: 13122016

๑) 2016 Association of Indonesian Islamic Kindergarten Teachers Education Study Program

\begin{abstract}
Abstrak Pendidikan keluarga merupakan pendidikan yang pertama dan utama bagi anak usia dini, di mana sebagian besar waktunya berada di lingkungan keluarga. Fungsi keluarga sebagai wahana pengasuhan, pendidikan, sosialisasi, mengembangkan kemampuan, dan membangun kebiasaan-kebiasaan positif bagi anak-anak. Orangtua adalah orang yang pertama dan utama yang harus bertanggung jawab menciptakan lingkungan kondusif, yang religious, memberi teladan kepada anak-anaknya agar mereka tumbuh menjadi anak sholih dan sholihah, berakhlak mulia, berguna bagi agama, nusa, dan bangsa. M engasuh, membesarkan, dan mendidik anak-anak yang dilakukan oleh orangtua, ayah dan ibu secara bersinergi harus dengan kasih sayang, kesabaran, ketelatenan, keikhlasan, dukungan material dan moral, pengorbanan, dan berusaha menciptakan keamanan, kenyamanan, kesejahteraan, dan kebahagiaan bagi anak di dalam keluarga, tanpa ada kekerasan, baik secara fisik maupun psikologis. Masa usia dini adalah masa yang sangat penting dari keseluruhan perkembangan manusia dan anak usia dini merupakan kelompok yang rentan menjadi korban kekerasan oleh orang dewasa. Makalah kecil ini berikhtiar untuk memformulasikan pendidikan keluarga yang ramah bagi anak usia dini ditinjau dari perspektif Psikologi.
\end{abstract}

Kata Kunci: Pendidikan, keluarga, ramah, anak usia dini.

\begin{abstract}
Family education is the first and primary education for early childhood, where most of his time being in a family environment. The function of family is an instrument for the upbringing, education, socialization, develop skills, and build positive habits for children. Parents are the first and foremost who should be responsible for creating an enabling religious environment, be an example to their children so that they grow into children who Shalih and Shalihah, noble, useful for religion, homeland and nation. Parenting, raising, and educating children committed by parents, father and mother are should be synergy with affection, patience, diligence, sincerity, moral and material support, sacrifice, and try to create security, comfort, well-being and happiness for the children in the family, without violence, both physically and psychologically. Early childhood is a crucial time of the overall human development and early children are vulnerable to violence by an adult. This little paper endeavors to formulate a no-violence family education for early childhood viewed from the perspective of Psychology.
\end{abstract}

Keywords: Education, Family, no-violence, early childhood

\section{Introduction}

Family education is the first and foremost education for early childhood,by which they spend most of their times in the family. The function of a family is as place for upbringing, learning, 
socializing, developing their abilities, and building positive habits for them.

Parents are the first and foremost persons that have to be responsible for creating a secure environment, religious, good-model in upbringing and teaching their children in order their children have a good attitudes, behave sholih and sholihah, benefit to their religion, nation and country. However, most of parents educate their children ineffectively and it perhaps in term of violence. Thus, this paper tries to formulate a hospitable family education toward early childhood under consideration of the psychology perspective.

Why do early childhood become the object of the study? Because this period is a significant period from overall of human being development and as vulnerable group. Early childhood cover children from birth through age 5 . Those children are always classified as the golden age. The first five years of their milestone is the significant period to build Islamic positive character as the basic character that will be reflected to their rest of life and to determine their next experiences. In this golden age, parents should manage as well as possible to give the best education for them. According to Freud, the golden age is the most significant period from all of the human development periods because this period is the basic period of individual character building (M iller, 1993: 129). Adult personality is determined by the way they overcome their conflicts between their interest and the reality when they were in the golden age. This period is a highly eventful and unique period of life. as the basic life in mature period. Freud believed that experiences gotten since they were a child will not replaced by the following experiences except of as the result of modification. The fastest and the most learning happened in their first life mainly in the first year of milestone.

Why did this paper entitle "a hospitable family education"?. The idea comes from the condition in which the present education contains many violence, especially the violence against early childhood. This paper would like to pursue a hospitable education without violence inside. There are some reasons related to the importance of the hospitable family education, they are: (1). Both printed media and electronic media recently have issued about violence against early childhood, it keeps on increasing. Besides this problem is like an iceberg where the fact of violence against children has not been much more exposed. M oreover the violence against early childhood, whether it is worse or worst, serious or not, conscious or unconscious, purposeful or unplanned, has been happened as long as the age of this world. (2). Violence which is occurred at home or in the family is not exposed to public, even though relatives or the closest neighbor have been witnessing it, they would not report it or stop it because it is supposed as impolite thing to interfere the other family affairs. (3). It is agreeable when parents or adults do violence as it is supposed to educate and to discipline them. (4). Early childhood are vulnerable group, they easily become the objects. (5). Parents or adults in the family potentially become the subject of violence against early childhood because they have power. (6). The violence occurred at home is usually well regulated so that their surroundings could not notice them and detect them. It is continuously going on and the subject has legitimate to uphold the power in running down the function as educator for his/her children. (7). The object of violence among children as the vulnerable group can not reject it and go beyond the violence circle. Most of the objects of 
violence keep stay at home fearfully and feel traumatic. The rest sometimes come to dead ends, disabled physically or mentally, and only a little part of them are able to escape and get help from their environment.

However, the violence against children whether it was done by parents or adults, are not justified. Whatever the causing factors are, all of those behaviors are prohibited. A ny children' attitudes and behaviors could not be the reason of doing violence. Any else, if they become the object, they are not fully blamed (not blaming the victim). The subject of violence against children must be blamed and must be responsible for his/her behavior, because parents and adults should be able to ensure their children' secure, safety, comfort, well-being and health under their care. It is not the opposite whatever the reason is.

\section{The fact of violence against early childhood}

In our social reality of Indonesia, the problems faced by children are more complex and vary, such as homeless children and beggar which increase rapidly, the smoking babies, the terrible injury caused by the smack down, sexual harassment by their closer friend, children exploitation by parents and human trafficking.

Violence among the family members is often unnoticed and not reported because there is no a secure way and believable person for children or adult to report it. In some parts of the world, people do not believe in police, social worker or people surroundings. The other hand, especially in rural area, there is no government institution which is able to be accessed, where every person can report their cases.

\section{The types of violence against early childhood}

WHO defined violence against children is the use of physical strength and power purposefully, both in term of threat or real action against children by individual or a group causing the real impact that will harm their healthy, their life progress, their development, and their prestige.

The type of violence commonly varies between male and female. The result of this research showed that early childhood gets the most risk of physical violence. Whereas the sexual harassment dominantly happened to whom has reached puberty or teenager. Males have more risk on getting physical violence than females, females have more risk on getting sexual harassment, neglecting, and human trafficking.

Violence against children varies and it is affected by many factors, could be from their own personality, the subjects or the environments socially and culturally. Violence against children can be classified as follows: (1) Physical violence, for example: banging his head, hitting, kicking, strangling, torturing physically, punishment and killing; (2) Verbal violence, for example: speaking rudely, insulting, expelling, and scolding; (3) Economy violence, for example: no feeding, neglecting, and isolating; (4) Psychological violence, for example: insulting, underestimating, bullying, scolding and giving trouble; (5) Sexual violence, for example: violation, sexual harassment, sodomy, rape. 


\section{Trigger factors from the occurrence of violence}

M ost of the violence against children are hidden because some causes and reasons, one of them is dread. Many children are afraid of reporting the violence against them. Thus, parent that should protect their children, keep silent when the subject is his/her spouse or his/her relatives even the big man in their society as the host, the policeman, or the authoritative person. The dread is closely linked to the paradigm which is frequently applied into violence reports, especially in a place where "the honor" of a family is positioned over children' safety and prosperity. Implicitly, violation or any kind of sexual harassment can cause isolation, the next violence or the death, so that this violence keeps going on because it is tolerated socially could be for the helpless object or the subject. In this term, physical, sexual and psychological violence are viewed as unavoidable matter of life and it is a normal situation. Physical punishment to discipline them, to discredit them, to frighten them and sexual harassment is viewed as normal thing, especially when there is no concrete consequence and serious physical injury that persists for long time.

The impact of violence against children varies depending on the level severity of violence. There is a short term physiological impact such as physical injury that can be healed, and there is also a long term physiological impact such as broken bone that affects hobble, paralyzed, and permanent disabled. Psychologically, the impact of violence can inflict social skill ability, emotional, cognitive, depression, traumatic, hallucination, anxiety, and memory. Sexual harassment against children affects deviant behavior such as early sexual behavior, deviant sexual behavior, and aggressive behavior.

The impact of physical violence against early childhood inflict permanent damage or even the death, even though the subject in fact injures unconsciously. The research from around the world showed that shaken baby syndrome is often related to the wound on his/her head and serious brain injury. Though in common, violence against children in the family is not fatal and does not cause serious injury (Flodmark, 2004:434).

The trigger factors from the occurrence of violence against children includes a relative, school community, society, mass media, TV, or internet. While the prevalence of violence against children has been done by their parents and the other family members are in the form of physical violence, mental violence, sexual harassment and purposeful neglecting have been admitted and documented for the recent decades.

Violence against children in the family are able to occur in the context of discipline and in term of physical, rude and discrediting punishment. Physical violence are often followed by psychological violence, as like insulting, worse labeling are the violence which threaten psychological development and welfare of children, mainly when the insulting habit was done by respected adults such as parents, grandparents, and relatives. It is urgent to support parents to use discipline method without violence.

Besides violence occurred in the family, children also become the object of violence done by their teachers or their classmates and even being kidnapped. They vulnerably get violence on 
the way home. For them, the experience back and forth to school or when they are doing their tasks from their parents as buying something to the food stall, delivering something to their neighbor, or getting mineral water, which force them to walk, make them vulnerable to become the object of violence.

Vulnerable children also become the object of sexual exploitation from their surroundings. Sexual harassment is commonly undertaken by respected person or familiar person which has power even though they do not know who they are. Furthermore, the mass media both printed and electronic such as videos, TV, movies, and internet perform violence scene, pornography, sexual harassment, bullying, and intimidation against children and it is supposed as normal act.

In a brief, the trigger factors from the occurrence of violence in the family as follows:

1. Unexpected marriage from one of the spouse or both couple, or married by accident, forced by their parents, or one of the spouse is not ready to get married.

2. Unexpected birth because a couple are not ready being parents, unexpected sex identity from their baby, disabled baby, or being doubtful toward their own baby.

3. Inharmonious relation of a spouse because of many reasons, for example: immature, jealous, unexpected marriage, poorness, getting conflict with their parents/parents in law/ sister in law/ brother in law, or they still live together with their parents.

4. Unstable welfare,jobless, earning no money, dependency, uncaring parents who force their children to earn money by themselves.

5. The low education level of a spouse so that they do not understand their rights and duties being parents, their little understanding toward their roles and functions of each toward their children.

6. The narrow religion understanding of a spouse so that they can not receive their new roles being parents to care their children, and they do not understand that their children are priceless granted from God.

7. Different perception and expectation between husband and wife toward their children.

8. Immature thought and mental of a spouse.

9. The lack of knowledge toward children' characters and the ignorance to learn from an expert or from the trusted sources.

10. The low caring knowledge of parents and the ignorance to learn from an expert or from the trusted sources.

11. The type of personality, especially their emotional feelings that tend to not able to control their emotional when facing their marriage problems.

12. Their parenting style which is mostly authoritarian tend to trigger the act of violence, because their parenting style needs more obedient that gives good responses toward children' wish. Their relationship built is full of frightening atmosphere, violence, rules, doctrine, punishment, blaming, forcing, controlling, prohibiting, one way communication, and never giving trust toward children to create.

From some factors above, almost all of the factors have similar problem core, it is from parents themselves and the relation between them. It is then released against their children. 
When one of them or each of them got problems, their children would be the object of their frustration, moreover when they do not understand that their children' character is developing, active, exploring, coping, trial and error time, and experiencing so that they are often called by "naughty kid", it is because they always make their parents angry, tired, and waste much energy in caring and educating them.

Although, there are many trigger factors for the occurrence of violence, but there are also restraint factors, they are family (parents), school-place, and society. The first factor is family which covers a harmony atmosphere and stable family, an authoritative parenting style toward their children, emotional interrelationship between parents and children, and discipline system without violence. A stable family can become powerful sources to protect their children against the act of violence in all societies. The second factor is school-place which covers a democratic and egalitarian school policy, an effective curriculum which supports character building, ante violence and non discriminant attitudes, a comfortable school environment, full of brotherhood, and religious enough. The third factor is society which covers an emotional interrelationship among the individual in the society closely and kinship. The high cohesion of society and the high level of religiosity of a society have protective effect against violence in a society, even though another factor also takes a risk.

Early childhood spend their time in adults' caring in the family more than in the society, and only a few that spend their time at school. School has a significant role to protect children against the act of violence. Adults which control and work at school environment have a task to provide a secure environment for children.

\section{A hospitable education formulation for early childhood}

As we remember that vulnerable children become the object of violence, thus it is needed to arrange a hospitable education program for early childhood in order they can be protected from the act of violence by parents or adults by holding principle that (1). There is no violence in any forms that is justified. A child has to get more protection than adult. (2). Any forms of violence against children can be prevented. The society and government must apply a policy and a program to handle the triggering factors against children, (3). Vulnerable children get violence related to their early ages, the weak of social status compare to adult, the disability or the difability owned by them such as blind, paralyzed, deaf and mute, (4). A child has right to get secure life, comfortable life, welfare and healthy life mentally and physically.

Some aspects that should be focused by parents and other family members in creating a hospitable family education toward early childhood are as follows:

1. Caring, parenting, and educating children should be done by parents lovely, patiently, calmly, sincerely, material and immaterial supports, sacrifice, and try to create tranquility, pleasure, welfare, and happiness situation of the family, no physical and psychological violence.

2. The age of husband and wife must be mature enough to get married. Although there is no definite restriction in determining the maturity of a spouse to get married, but the marriage requirements as stated on the law of marriage is about the minimal age, however ideally it is 
needed a few years more to gain better maturity, for example: a husband and a wife have finished bachelor degree (for about above age 24 for male and above age 22 for female to get married).

3. The family has good income to meet their needs. This earnings is not definitely described, but it minimally has fixed income or has willingness and motivation to earn money which is able to be undertaken by husband or together with his partner.

4. Education level of a spouse has been sufficient to comprehend each function and task as parents for their children, to comprehend their duties toward their children, and also to comprehend their children' rights to be fulfilled by themselves as parents.

5. The willingness to learn about a good parenting and comprehend early childhood character from their grandparents and the trusted sources.

6. Endeavor holding up their emotion and learn to be patient, accept the physical and characteristic of children in a whole.

7. Willing to assist in developing their children' interest and talent as maximally as possible by facilitating them based on their need.

8. Each children has their own characteristic, personality, interest, talent, and unique skill and different from others, so parents should not compare them.

9. Have beliefs that basically a child is pure and kind (fitrah). If a child grows and develops badly, parents should introspection on themselves, whether their parenting and educating given to them are efficient enough or not. For that reason, parents should not isolate themselves to share and counter from other parents' experiences.

10. Always realizing that an effective education for early childhood is through coping, good modeling, habituating, conditioning, strengthening, rather than direct teaching verbally.

11. Each parents is expecting that their children become shalih/shalihah, to achieve it parents should be religious first in order to be coped by their children.

12. Teach religious norms, social norms and moral norms toward early children as early as possible. Introduce their sensitive area which could not be touched or seen by anyone. Also teach how to repel someone when he will touch, see or attack their sensitive area although it is from their own family members which has opposite sex.

13. Correct their behavior soon if they behave beyond their habits.

14. Strengthen and appreciate them anytime they behave politely.

15. Always be aware of a child will be a child who differs from adult in terms of skill, interest, and talent so that parents can determine their target and their expectation realistically, the target differs from adult, or a child can not be the target of parents' ambition.

16. Make sure that children is in the secure family that always protect him/her from the disturbance of people surroundings both inside and outside.

17. Always monitor children' activities at home, outside, when with their friends or when they are at school.

18. Create a harmony relationship between parents or family members and children at home by inviting to tell a story frequently and share experiences with their parents. 
19. Accompany them when they watch on TV, video, operating gadget, or playing games on computer, express positive moral message from the shows they watch.

20. Dispose time and enough attention to communicate with them. Listen actively what they said from their previous experiences. Give strengthening and appreciation toward their positive attitudes and remind them firmly and warmly toward their negative attitudes. Tell the consequence or the result of their negative behavior.

21. Entrust children to the trusted person or maid if parents would like to let them at home. $M$ ake sure that they are safe.

22. Ask and investigate when parents find strange behavior of their children beyond their habits.

23. Create a harmony, secure, and comfortable home so that children feel comfort and feel at home.

24. Control what children watch and read, do not get watching unworthy shows as like pornography, violence or quarreling.

25. Parents and family members should speak politely and assertively in communicating with their children.

26. Willing to listen children' talks completely, uncut, unjustified, no directly answered till it is clear what they talk.

27. Express love explicitly, adequately and effectively.

28. Communicate to grandparents, maid, and other family members about children' characteristic and effective behaviors conform to their characteristic.

29. Teach children to understand and habituate doing their tasks independently.

30. Avoid rude talks, shouting, scolding, insulting, underestimating, threatening, scaring, lying, useless swearing, much talking, bad labeling which is disliked by them.

31. Build synergistic between husband and wife so that shared parenting can be run well.

32. Put them as a friend in communicating.

33. Build daily conversation and share information naturally and warmly.

34. Address their names when talking with them.

35. Use various methods to stimulate and to improve their language development.

36. Talk to anywhere and any chance needed by children.

37. Adjust using polite talk for many reasons.

38. Speak using adults' talks broadly.

39. Speak various new words to improve their language vocabularies and their cognitive skills.

40. Religion teaching toward early childhood covers: (a). Faith unto Allah, mainly Allah is the only creator who knows His creature behaviors. (b). Worship especially prayer and fasting. (c). M orals, (d). Learning Al-Qur'an.

41. Faith teaching method unto Allah for early childhood could use story telling methods, song, real example, parable and analogy toward human character but in the level of anthropomorphic based on the cognitive development which is delivered in a concrete, brief, clear, and simple language, connected with their daily life, matched to their intellectual level, done patiently, step by step, non doctrinal, does not oppose to the received concept at home 
and at school, and could be delivered informally and pleasant atmosphere.

42. Worship teaching method toward early children by using example method, modeling, habituating, socializing, exercising, conditioning, story telling, practicing, brief and concrete explanation, and involving affection, emotional, attention, and motivation, which is done patiently, calmly, continually, gradually, continuously and consistently, it is also done in a friendly, warm and fun atmosphere, its activity can be done together in a family habit and can use audiovisual tool, visual aid, and illustrated book, it is also done in synergy manner between parents at home and teachers at school, and needs to give reward when a child can do his/her activity correctly based on his/her parents' teaching.

43. M oral teaching method toward early childhood by using modeling, habituating, story telling, narrating of shalih or shalihah person, explanation of cause and effect using concrete, practice and simple language, use audiovisual tool, visual aid, illustrated book, and real example. it is also done in synergy manner between parents at home and teachers at school, gives reward and strength when a child shows good behavior, attitude, and moral, and gives understanding about the consequences when a child behaves badly.

44. Al-Quran learning method toward early childhood by using the existed method as like Iqra or Qira'aty, or using another method which is simple, easy, no spelling, using Al-Qur'an language of Arabic, based on the Tajwid principle, and Makharijul-huruf, step by step, continually, patiently, calmly, continuously, in a joyful learning, flexible, both its time and its place, varies and there is interlude method and related activity as like reading prayer, the stories of prophets and their disciples, poem, religious songs, shalawat nabi, and any others to avoid saturation and take their spirit back. It is more effective when it is done frequently and in a short time than once but long time, it can use audiovisual aid, CD, Iqro'/Qiro'ati book, giving reward, attention individually, and in group, doing many exercises, and repetition, it needs to correct their errors at the time, also it is done in synergy synergy manner between parents at home and teachers by applying different method.

There are still so many significant points which can be added in the way of creating a hospitable family education without violence for early childhood in the Islamic family setting. The formulation above is not something rigid, but at least it can assist to identify some significant aspects which need much attention to their beloved children in order they grow and develop based on their parents' expectation in the fun and joyful atmosphere, because children' happiness psychologically will bring them being shalih or shalihah person when they will have been adult later.

As the guide, religion education which is taught toward early childhood according to Abdullah Nashih U Iwan can be done through some steps below:

1. Let the first words of "La ilaaha illa Allah" listened to them and pronounce it as Nabi SAW said "let the first utterance of "La ilaaha illa Allah" listened to your children" (H.R. Hakim dari I bn Abbas RA).

2. Known them with the law of Halal and Haram, as Nabi SAW said "teach your children to perform their faith unto Allah SWT, afraid of behaving sin, perform Allah's message and 
avoid Allah's prohibition, thus is better as your protect in spite of in the hell' (H.R. Ibn Jarir dan Ibn Mundzir dari Ibn Abbas RA).

3. Command your children to pray when they are seven years old, as Nabi SAW said "ask your children to pray when they are seven years old, and beat them (act firmly) when they are ten years old, and separated them, teach fasting when they will have been strong, take them to go hajj when you are capable of doing that" (H.R. Hakim \& Abu Daud dari Ibn U mar \& Ibn Ash).

4. Educate them to love their prophet and his family, also learn Al-Qur'an, as Nabi SAW said "educate your children covers: love your prophet, his family, and read Al-Qur'an because in truth Al-Qur'an is in arsy' on Allah's hand on the day when no patronage except the patronage of Allah, Anbiya and Ashfiya" (H.R. Thabrani dari Ali KW).

\section{Conclusion}

Whatever the reason is, violence against children in any types is not justified, has to be stopped and prohibited. However, violence against children occurred in each country, cross over the culture, social class, education, economic status and ethnic.

By struggling to formulate no violence education, it is expected to be able to end up the justification of violence against children by adults, is it received as "tradition" which is hidden or is it a form of discipline?. Each society, whatever their cultural , economic and social background is, able to and have to stop violence against children, this does not mean giving punishment for the subject, but it needs the transformation on the way of thinking of a society which is linked to the act violence.

\section{References}

Ulwan, N. A. (tanpa tahun). Tarbiyah Al-Awlad fi al-Islam. Juz I. Beirut: Daar as-Salam li al-Thabaah wa al-Nasyr wa al-Tauzie.

Miller, P.H. 1993. Theories of Developmental Psychology. $3^{\text {th }}$. Ed. New York: WH. Freeman and Company.

Krug, EG . et al. 2002. World Report on Violence and Health. Geneva: WHO

Felitti, V.J. et al. 1998. "Relationship of childhood abuse and household dysfunction to many of the leading causes of death in adults. The Adverse Childhood ExperiencesStudy". American Journal of Preventive M edicine, [14]:

Flodmark, O. 2004. "Imaging in battered children”. Rivista di Neuroradiologia. [17]: 434.

Hart, S.N . ed. 2005. Eliminating Corporal Punishment. Paris: UNESCO. p. 52 